\title{
PROJETO GENOMA: A BUSCA INCANSÁVEL PELA EUGENIA
}

\section{Genome project: the untining search for eugenics}

\section{Resumo}

\author{
Sidney de Oliveira Souza ${ }^{1}$
}

0 conhecimento advindo da decodificação do código genético trouxe à tona sérias questões de ética. 0 "livro" do genoma traz promessas de benefícios às pessoas, como tratamentos definitivos para o câncer, doenças cardíacas e outras enfermidades. Mas traz também lembranças do pesadelo nazista, das políticas de eugenia contra portadores de genes ligados a doenças e quaisquer outras características físicas. Os mesmos testes de diagnóstico que poderão ajudar uma pessoa com predisposição genética para doenças cardíacas a prevenir complicações poderão ser usados por seguradores e empregadores para discriminá-la. Se exames feitos ainda no útero da mãe mostrarem que uma criança sofre de uma doença genética com incapacidade física ou mental, quais parâmetros serão analisados na interrupção da gestação? Neste artigo, serão ilustradas algumas dessas situações com o objetivo de propor uma discussão franca na sociedade a respeito do genoma e seu impacto na humanidade.

Palavras-chave: G enoma; Eugenia; Ética; Código genético; Progresso científico.

\begin{abstract}
The knowledge brought by the decoding of the genetic code brought several ethical questions. The book of the genome brings beneficial promises to the people, as definitive treatments for the cancer, cardiac illnesses and other diseases. But it also brings the nazi nightmare memories, eugenic policies against carriers of on genes linked to illnesses and any other physical characteristics. The same diagnosis tests that will be able to help a person with genetic predisposition cardiac illnesses to prevent complications could be used for insurers and employers to discriminate it. If done examinations still in the mother's womb to show that a child suffers from a genetic illness with incapacity physics or mental, which parameters will be analyzed in the interruption of the pregnancy? In this article, these situations will be illustrated with the objective of to propose a frank discussion in the society regarding the genome and its impact in the manked.
\end{abstract}

Keywords: Genome; Eugenics; Ethics; G enetic code; Scientific progress

${ }^{1}$ Sidney de O liveira Souza. Rua França, n.ำ 260, Espigão Regente Feijó - São Paulo 19575-000. E-mail: siamf@ig.com.br. Graduando de Bacharelado em Sistemas de Informação na Universidade do O este Paulista UNOESTE. 


\section{Introdução}

Este artigo é resultado de uma pesquisa bibliográfica que tem por objetivo avaliar os impactos do Projeto Genoma na sociedade, tendo por base parâmetros éticos. Além de demonstrar a busca do homem pela eugenia desde tempos antigos, propõe evidenciar também que a incessante busca pela melhoria da espécie motivou 0 avanço da humanidade em diversos aspectos. Porém, em outros, fomentou alguns dos períodos mais nefastos da história humana. A humanidade produziu um grande número de clássicos da literatura, fontes de cultura e inspiração. Agora, pela primeira vez, tem-se uma antologia da espécie humana, que conta uma história de bilhões de anos de evolução. Assim, o Projeto G enoma Humano (PGH) pode ser descrito como o livro da vida, ou a antologia do homem. Comparado pela revista científica Nature (1) aos eventos históricos mais importantes, o Projeto de Seqüenciamento do Genoma Humano representa um marco fundamental na evolução de todos os estudos da vida humana, bem como na estruturação de pesquisas biomédicas.

Há os que acreditam que 0 mapeamento do código genético é um avanço que encontra precedente parecido somente se comparado à Teoria da Evolução das Espécies de Charles Darwin (2). Em princípio, pode até parecer exagero dos entusiastas do Projeto Genoma, mas não há como negar que o seqüenciamento de 3 bilhões de nucleotídeos (Bases de DNA) que compõem o Genoma humano é uma descoberta fascinante e descrita pela Nature como "tão significativa quanto a viagem à Lua, a fissão do átomo e a invenção da roda" (1).

A representatividade do genoma é tamanha que 0 relacionamento do homem com sua própria biologia nunca mais será 0 mesmo, pois será detentor do conhecimento de identificar todos os genes que comandam a complexa estrutura biológica dos seres vivos e como bem fundamentou Bacon "conhecimento é poder" (3). Porém, a grande pergunta que ecoa pelo pensamento de todos é como tirar partido de toda a informação já obtida com o seqüenciamento dos genes para resolver as mais diversificadas questões da ciência biológica? Identificar a seqüência dos genes não significa dominar sua manipulação, mas é a melhor maneira para se conhecer nossa ingenuidade perante tais questões e assim definir qual a extensão do caminho que temos a percorrer.

Conforme Sabbatini (4) observou, podese traçar um paralelo do genoma com 0 mito grego de Pandora. Foi dada a Pandora pelos Deuses uma caixa que jamais poderia ser aberta, pois eram guardados nessa caixa todos os males do mundo. Pandora, tomada de extrema curiosidade, abriu-a para olhar. Nesse momento, espalharam-se todos os males pelos confins da Terra. Analogamente, com relação à história da ciência, a caixa foi aberta pelos cientistas ingleses James Watson e Francis Crick, quando decifraram o modelo molecular do DNA. Foi essa "abertura da caixa" que ofereceu subsídios para todas as pesquisas no campo da genética, passando pela clonagem até culminar no projeto Genoma. Os mais tradicionais acham que essa caixa jamais deveria ter sido aberta, pois não é conhecido seu conteúdo e o desconhecido sempre foi um elemento de temor para o homem.

Em 1990, o Papa João Paulo II, ao receber cientistas que faziam parte de um congresso sobre medicina fetal, proferiu a frase "É melhor não saber", ou para bom entendedor "D eixem a caixa fechada" (5).

Com relação ao impacto na sociedade, a caixa foi aberta com 0 advento da clonagem e a divulgação de seu expoente mais famoso, a ovelha Dolly. Suscitando uma série de críticas ao processo de clonagem, onde a mais contundente é a de que para se conseguir um único clone perfeito são criadas várias outras cópias sem nenhum sucesso, clones com defeitos terriveis e outros tantos morrem em algum estágio de desenvolvimento. Para os críticos da técnica clonagem humana então seria impraticável.

\section{Superioridade Genética}

Existe ainda muita confusão no que tange a assuntos relacionados à genética. Muitos confundem Clonagem com 0 
Projeto Genoma. Embora intimamente ligados, pois ambos tratam de engenharia genética, são bem distintos em seus processos. Um clone é a cópia de um ser vivo a partir do núcleo de uma célula, e toda a seqüência de D NA da cópia é idêntica a do doador da célula, inclusive seus defeitos (6). O Projeto Genoma, por sua vez, visa a seqüenciar os genes e verificar em que seqüência do código genético existe um gene defeituoso. Vale ressaltar que a junção dessas técnicas resultaria em uma cópia melhorada, embora o termo cópia perca sua conotação, pois nesse caso a "cópia” difere do original pela ausência de defeitos. Dessa forma, os genes defeituosos responsáveis por defeitos congênitos, transmissões hereditárias de características indesejáveis ou doenças, mutações e genes com prédisposição ao câncer ou qualquer outra doença seriam substituídos. Naturalmente, todas essas maravilhas são de caráter empírico, ou seja, são apenas especulações e ainda estão em fase de experimentação.

No entanto, este é o grande trunfo dos defensores das pesquisas do Projeto Genoma, a chamada terapia gênica, justamente a substituição de partes do código genético no qual fica caracterizada uma limitação ou doença.

Isso nos remete ao filme Gattaca: experiência genética, uma crônica futurista que, na visão do diretor Andrew Niccol, retrata uma sociedade perfeita em que a eugenia (melhoria da espécie) é a palavra de ordem. Nessa sociedade, as pessoas normais, chamadas de "inúteis", são vítimas de preconceitos e relegadas em um nível social inferior, ficando com as funções menos nobres. 0 diretor coloca em cheque o futuro da manipulação genética no qual pessoas normais são preteridas em detrimento de pessoas geneticamente superiores. 0 filme faz uma abordagem ética e filosófica sobre uma sociedade que vive sob o signo da engenharia genética e questiona se a chave do sucesso está realmente nas seqüências do genoma de um cidadão. Poucas vezes um filme futurista foi tão plausível em sua abordagem quanto aos rumos que a ciência genética provavelmente tomará.

Evocando mais uma vez os mitos, a preocupação com a superioridade humana não é nova, o mito de Prometeu assinala isso de forma clara. Prometeu foi o criador da primeira civilização humana, depois de criar o homem, rouba, para animálo, o fogo do céu, porque desejava que sua criação fosse superior a todas as outras formas de vida. Com o dom do fogo, o homem obteve os meios de construir armas, ferramentas e aquecer-se, mas foi além (7).

\section{Admirável Mundo N ovo}

Huxley (8) faz uma crítica à busca incessante da superioridade genética e mostra o pesadelo da eugenia em uma sociedade controlada geneticamente. Nesta sociedade, as pessoas que não se enquadram no conceito de perfeição são relegadas a atividades braçais. Fica evidente que Andrew Niccol bebeu na fonte de Huxley (8) para compor seu filme. Huxley (8), em sua distopia, exprime toda a angústia que 0 homem experimenta ao viver em uma sociedade perfeita, porém carente de emoções. É impressionante como o texto soa profético nos dias de hoje em que a ciência parece carecer de reflexão sobre quais rumos a humanidade tomará no que se refere aos avanços científicos e tecnológicos. A tualmente é possível, pela análise genética, obter um diagnóstico pré-natal de doenças como a Síndrome de Down ou de fetos anencéfalos (9), motivos que os defensores da interrupção da gestação consideram suficientes para aumentar a eficiência do aborto eugênico. O genoma, por sua vez, poderá fornecer um diagnóstico pré-natal de uma gama vastíssima de doenças e também características físicas, como cor dos olhos e dos cabelos, além dos chamados distúrbios comportamentais, tais como psicose maníacodepressiva, esquizofrenia e propensão ao alcoolismo ou à dependência de drogas presentes nos genes de comportamento. Nesse contexto, qual será 0 parâmetro para realização do aborto gênico, o que influenciará nossa consciência para se determinar quais características terá um ser vivo? Cor dos olhos? Propensão ao alcoolismo (10)?

No futuro imaginado por Huxley (8), apesar de relativamente distante, 0 aborto gênico provavelmente ficará 
descontextualizado porque será dada ao homem a possibilidade de escolher quais características serão eliminadas e quais serão adicionadas antes da criação do ser, ou seja, será a era do advento dos "bebês de prateleira". Não seria apenas corrigir eventuais problemas de saúde, mas aperfeiçoar funções do corpo, ou utilizar-se de recursos híbridos para adicionar funções não inerentes ao homem, como, por exemplo, a faculdade de regeneração de órgãos ou a velocidade nos movimentos que são características intrínsecas a algumas espécies. E é nesse mote que há profundas e impactantes discussões sobre a ética. Desse modo, tornam-se muito tênues os limites da criação humana, é o homem brincando de ser Deus. Zatz (10) discorre sobre esses assuntos com mais detalhamento ao analisar os genes de comportamento, escolha de sexo, doenças genéticas e o diagnóstico prénatal e 0 problema da interrupção da gestação, identificando a complexidade de algumas circunstâncias e a dificuldade de se tomar decisões visando ao bem dos envolvidos e principalmente estimular a discussão ética desses assuntos na sociedade.

O s mais céticos podem não acreditar que tais intentos se realizarão um dia, mas deve-se ponderar que se há algo que possa ser realizado, invariavelmente, esse algo será realizado por alguém. Ou alguém acreditava há 500 anos, quando Leonardo Da Vinci esboçou os primeiros protótipos de uma máquina voadora, que 0 homem pudesse realmente voar.

\section{Bebês de Prateleira}

Menconi (11) argumenta que os integrantes do Projeto Genoma Humano esperam que os testes para a detecção de doenças terão a acuidade necessária no prazo de uma década. Mas muitas empresas já intensificam suas pesquisas a fim de obterem o domínio comercial de segmentos do código genético, a matéria-prima para a elaboração de remédios realmente eficientes. A exploração mercantil não constitui um aspecto negativo, pois é inegável que uma inovação tecnológica só tem sucesso se puder ser explorada em nível econômico.
Ao menos no que diz respeito aos "bebês de prateleira", guardadas as devidas proporções é claro, o sexo já pode ser escolhido por reprodução assistida. Brasil (12) destaca duas técnicas para a escolha do sexo do bebê. Uma é a seleção do sêmen que requer inseminação artificial e tem quase $70 \%$ de chance de sucesso. A outra, denominada PGD (diagnóstico genético préimplantacional), é mais agressiva e exige fertilização in vitro; porém o índice de sucesso é de $100 \%$. De certa forma, pode parecer uma comparação um tanto agressiva. Mas qual a diferença no conceito de "bebês de prateleira" e o genocídio praticado por Adolph Hitler na Segunda Guerra Mundial? Hitler ordenou que milhões de judeus fossem dizimados em nome da chamada "raça pura" idealizada por ele e que portadores de deficiências físicas e mentais servissem de cobaias para experimentos genéticos realizados por Josef Mengele, "médico" de confiança do Füher (13). Pode ser que a diferença esteja no contexto de brutalidade em que Hitler idealizou sua "melhoria da raça", mas de qualquer forma 0 cerne da questão continua sendo o mesmo, trata-se de eugenia. Os atos de Hitler refletem a aversão em se conviver com a condição de fragilidade humana, aversão que está presente na humanidade desde épocas ancestrais e que hoje possui uma aliada poderosa na ciência que prega o progresso científico a qualquer custo. Há que se temer o desejo desenfreado em se obter a melhoria da raça, pois este anseio fomenta um câncer social perigoso: o preconceito, cujo sintoma mais evidente é a intolerância, tendo a ver com o que foi incutido como valor em cada cidadão.

\section{Árvore da Vida}

O homem é um eterno insatisfeito e essa insatisfação é, desde tempos remotos, a força motriz para todos os avanços da humanidade. $\mathrm{Na}$ busca desenfreada por satisfazer-se, 0 homem desconhece 0 sentido de limite em suas realizações. Essa intrepidez seria uma característica positiva se não esbarrasse em uma palavra, velha conhecida dos progressistas: a ética. D este modo, quando o genoma incutir ao homem 
uma expectativa de vida longa, livre de toda e qualquer doença, estes serão benefícios triviais que não mais satisfarão ao homem, e este procurará satisfazer seu instinto primário, a sobrevivência, tão bem representada pela imortalidade, a mesma imortalidade buscada pelos alquimistas da Idade Média com seus experimentos em busca do elixir da longa vida. Os alquimistas contemporâneos não têm mais a figura solitária de um homem recluso em uma torre. Utilizam toda uma gama de recursos de comunicação e tecnologia para enfim encontrar escondido entre os códigos seqüenciados do genoma o tão sonhado elixir. Uma vez tendo satisfeito este instinto primário intrínseco ao homem, este não mais sentirá a necessidade de alimentar seu espírito, sentirse-á o seu próprio D eus, pois a fé em um Deus é a firme fundamentação de que a vida é efêmera e que após a morte física a vida continua em um plano mais elevado. 0 genoma figura então miticamente como a árvore da vida que havia no Jardim do Éden. Segundo Gênesis (14), existiam no Éden duas árvores, a árvore da vida e a árvore do bem e do mal, da qual não era permitido ao homem comer dos seus frutos, pois, se assim 0 fizesse, morreria. Hoje, com o genoma, o homem crê que encontrou 0 caminho para a árvore da vida e quer comer de seu fruto e, inversamente ao que ocorreu ao primeiro homem, que conheceu a morte ao comer do fruto da árvore do bem e do mal, deseja atingir sua imortalidade.

\section{Considerações Finais}

Mesmo com todo progresso científico e tecnológico e questões acerca desses progressos - se trarão ou não benefícios à humanidade - , toda a ação do homem deve ser regida pelo bom senso e pela ética. $\mathrm{Ou}$ seja, mesmo em tempos de Projeto Genoma Humano e de seu código genético inteiramente decifrado, mesmo em tempos de Clonagem e suas cópias idênticas, deve-se, ainda assim, ter um juízo sobre quais os valores a serem ponderados diante desses dilemas.

Mas se 0 futuro reservar situações em que não haverá uma reflexão crítica sobre tais valores, ainda restará um alento, as pessoas são dotadas de almas, algo que a ciência provavelmente não conseguirá decifrar ou reproduzir.

\section{Referências}

1. Sabbatini RME. O Livro da vida. Jornal Correio Popular, [on-line] 2001 fev16. [capturado14 abr. 2005]. Disponível em URL:http:/ / www.sabbatini.com/ renato.

2. Lima GS. Eles têm quase tudo em comum. Veja maio 2003; 36(21): 73-4.

3 Bacon F. Nova Atlântida. São Paulo: Nova Cultural, 1999.

4. Sabbatini RME. A caixa de Pandora. Jornal Correio Popular, [online]1998 jul 31. [capturado em 14 abr 2005]. Disponível em URL: http:// www.sabbatini.com/ renato.

5. Sabbatini RME. Genoma e o futuro. Jornal Correio Popular, [online] 2000 jul 7. [capturado em 14 abr 2005]. Disponível em URL: http:// www.sabbatini.com/ renato.

6 Pereira LV. Clonagem: fatos e mitos. Jornal Conselho Regional de Biologia de São Paulo, [online]1999 13 ago. [capturado em 22 abr 2005]. Disponível em URL: http:/ / www.radiobras.gov.br/ et/ artigos/ 199 9/ artigo_130899.htm.

7. Bulfinch T. O Livro de ouro da mitologia: a idade das fábulas: História de deuses e heróis. Rio de Janeiro: Tecnoprint; 1965.

8. Huxley AL. Admirável mundo novo. 16 ed. Porto Alegre: G lobo; 1985.

9 Lima MA. Doenças humanas cromossômicas. [on-line] 2005. [capturado em 28 abr 2005] Disponível em URL: http:/ / www.ufv.br/ dbg/ BIO 240/ DC 04.htm. 
10. Zatz M. Projeto Genoma Humano e Ética. São Paulo em Perspectiva 2000; 14(3): 47-52.

11. Menconi D. Show dos milhões. Isto É fev 2001; 1637: 62-3.

12. Brasil S. Menino ou menina? Você já pode escolher. Veja set. 2004; 37(38): 100-107.

13. Pedrosa PSH. Eugenia: O Pesadelo genético do Século XX. Parte III: a ciência nazista. [on-line] 2005. [capturado em 22 abr 2005]. Disponível em URL: http:/ / www.montfort.org.br/

14. Bíblia Sagrada. São Paulo: Sociedade Bíblica do Brasil, 2004. Gênesis 2, 16,17/ 3, 1-24.

Recebido em 03/ 05/ 2005; aceito em 31/ 05/ 2005

Received in 03/ 15/ 2005; accepted in 05/ 31/ 2005 